\title{
Gas chromatography-mass spectroscopy analysis of bioactive petalostigma extracts: Toxicity, antibacterial and antiviral activities
}

\author{
F. R. Kalt ${ }^{1}$, I. E. Cock ${ }^{1,2}$ \\ ${ }^{1}$ Biomolecular and Physical Sciences, and ${ }^{2}$ Environmental Futures Centre, Nathan Campus, Griffith University, \\ Nathan, Queensland 4111, Australia
}

Submitted: 02-04-2013

Revised: 01-05-2013

Published: 21-02-2014

\section{A B S T R A C T}

Background: Petalostigma pubescens and Petalostigma triloculare were common components of pharmacopeia's of multiple Australian Aboriginal tribal groupings which traditionally inhabited the areas in which they grow. Among these groups, they had a myriad of medicinal uses in treating a wide variety of bacterial, fungal and viral infections. This study was undertaken to test $P$. pubescens and $P$. triloculare leaf and fruit extracts for the ability to inhibit bacterial and viral growth and thus validate Australian Aboriginal usage of these plants in treating bacterial and fungal diseases. Materials and Methods: $P$. pubescens, and $P$. triloculare leaves and fruit were extracted and tested for antimicrobial, antiviral activity and toxicity. The bioactive extracts were further examined by RP-HPLC and GC-MS to identify the component compounds. Results: The methanol, water and ethyl acetate leaf and fruit extracts of displayed potent antibacterial activity. The methanol and ethyl acetate extracts displayed the broadest specificity, inhibiting the growth of 10 of the 14 bacteria tested (71\%) for the leaf extract and 9 of the 14 bacteria tested (64\%) for the fruit extracts. The water extracts also had broad spectrum antibacterial activity, inhibiting the growth of $8(57 \%)$ and $7(50 \%)$ of the 14 bacteria tested, respectively. All antibacterial extracts were approximately equally effective against Gram-positive and Gram-negative bacteria, inhibiting the growth of $50-75 \%$ of the bacteria tested. The methanol, water and ethyl acetate extracts also displayed antiviral activity in the MS2 plaque reduction assay. The methanol and water extracts inhibited 26.6-49.0\% and 85.4-97.2\% of MS2 plaque formation, respectively, with the fruit extracts being more potent inhibitors. All ethyl acetate extracts inhibited $100 \%$ of MS2 plaque formation. All extracts were also non-toxic or of low toxicity. Analysis of these extracts by RP-HPLC showed that the $P$. triloculare ethyl acetate fruit extract was the least complex of the bioactive extracts. Subsequent analysis of this extract by GC-MS revealed that it contained 9 main compounds: acetic acid; 2,2-dimethoxybutane; 4-methyl-1,3-dioxane; decane; unadecane; 2-furanmethanol; 1,2-benzenediol; 1,2,3-benzenetriol; and benzoic acid. Conclusion: These studies validate Australian Aboriginal therapeutic usage of Petalostigma species and indicate their medicinal potential.

Key words: Antibacterial, antiviral, Australian medicinal plants, euphorbiaceae, Petalostigma pubescens, Petalostigma triloculare, quinine bush

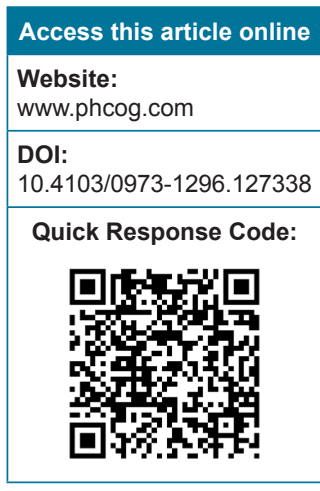

\section{INTRODUCTION}

Plants have been used for thousands of years as medicines for treating a variety of different diseases and medical complaints by most, if not all civilisations. Phytotherapy in Asia is particularly widespread and documented. Asian

Address for correspondence:

Dr. I. E. Cock, Biomolecular and Physical Sciences, Nathan

Campus, Griffith University, 170 Kessels Rd, Nathan,

Queensland 4111, Australia. E-mail: I.Cock@griffith.edu.au plant-based medications have been used in the treatment of numerous disorders including eczema, malaria and respiratory disorders. ${ }^{[1]}$ Similarly, plant based medicinal systems continue to be the primary therapeutic system in many parts of Africa. For example, Phytolacca dodecandra is used as a moluscicide in the control of schistosomiasis. ${ }^{[2]}$ Some African plant derived medicines have also found a place in modern Western medicinal systems. The antitumour agents vinblastine and vincristine (derived from Catharanthus roseus) are currently used in the treatment of a variety of tumours. ${ }^{[3,4]}$ Studies have also examined 
the myriad of medicinal plant uses by indigenous North, Central ${ }^{[5]}$ and South Americans. ${ }^{[6]}$ Approximately 1500 plant species are currently used in Europe to treat a wide variety of medical conditions. ${ }^{[1]}$

While much of the research into traditional medicinal plant use has focused on Asian, African and South American plants, recent studies have begun to examine the therapeutic potential of Australian medicinal plants. In particular, the antibacterial nature of Australian plants is receiving attention due to the development of super-resistant bacterial strains and the need to find new antibacterial agents. In recent studies in this laboratory, we have examined the antimicrobial activity ${ }^{[7,8]}$ and toxicity ${ }^{[0]}$ of various Australian native plants, many from the Toohey Forest area of Brisbane, Australia. Several plants were identified as having promising antimicrobial activities.

Petalostigma, an Australian genus of the Euphorbiaceae family, consists of seven species. Two of these species which occur in the Toohey Forest region (Petalostigma pubescens and Petalostigma triloculare) are collectively known as 'quinine tree'. The two species differ slightly in terms of leaf and fruit shape and size. ${ }^{[10]}$ Both trees grow to between 2 to 10 metres in height, with bright orange fruit. They are distinguished by the longer leaves of $P$. triloculare and the slightly larger fruit of P.pubescens [Figure 1]. Ethnobotanical evidence exists that an infusion of Petalostigma spp. bark or fruit in water is effective in relieving sore eyes, and as an antiseptic. Indeed, Petalostigma spp. were used extensively by Australian Aborigines to treat a myriad of bacterial, fungal and viral diseases. ${ }^{[1]]}$ Fruit was also held in the mouth by Australian Aborigines to relieve toothache. ${ }^{[11]}$ Despite this range of traditional medicinal uses, the phytochemistry and therapeutic potential of Petalostigma spp. has not been extensively studied. Although the common name suggests quinine is present within the fruit or leaves, there is no scientific evidence to support this.

While the therapeutic potential and phytochemistry of Petalostigma spp. has yet to be extensively examined, several other species of family Euphorbiaceae are known to produce diterpenes with cytotoxic, antitumor/tumor promoting and antimicrobial activities. ${ }^{[12,13]}$ Furthermore, a recent investigation into the chemical composition of $P$. pubescens heartwood identified five polycyclic diterpenes with antitumor activity: 5,9-syn-rosane petalostigmones $\mathrm{A}$ and $\mathrm{B}$ and erythroxylane petalostigmone $\mathrm{C}$, pubescenone, and sonderianol [Figure 1]. ${ }^{[14]}$ The current study was undertaken to determine the toxicity and antibacterial and antiviral activities of $P$. pubescens and $P$. triloculare leaf and fruit extracts. GC-MS analysis was used to examine the phytochemistry of a bioactive extract.

\section{MATERIALS AND METHODS}

\section{Plant collection and extraction}

P. pubescens and P. triloculore leaves and fruit were collected from Toohey Forest, Australia and were identified with reference to a taxonomic key to Toohey Forest plants. ${ }^{[15]}$ Voucher specimens (PPL090224, PPF090224, PTL090226 and PTF090226) were stored in Biomolecular and Physical Science, Griffith University, Australia. Samples were dried in a Sunbeam food dehydrator and then ground to a coarse powder. $1 \mathrm{~g}$ of plant material was weighed into each of five tubes and five different extracts were prepared by adding $50 \mathrm{ml}$ of methanol, water, ethyl acetate, chloroform, or hexane respectively. All solvents were obtained from Ajax and were AR grade. Leaf and fruit material was extracted in each solvent for 24 hours at $4^{\circ} \mathrm{C}$ with gentle shaking. The extracts were filtered through filter paper (Whatman No. 54) under vacuum followed by drying by rotary evaporation in an Eppendorf concentrator 5301. The resultant dry extract was weighed and redissolved in $10 \mathrm{ml}$ deionized water.

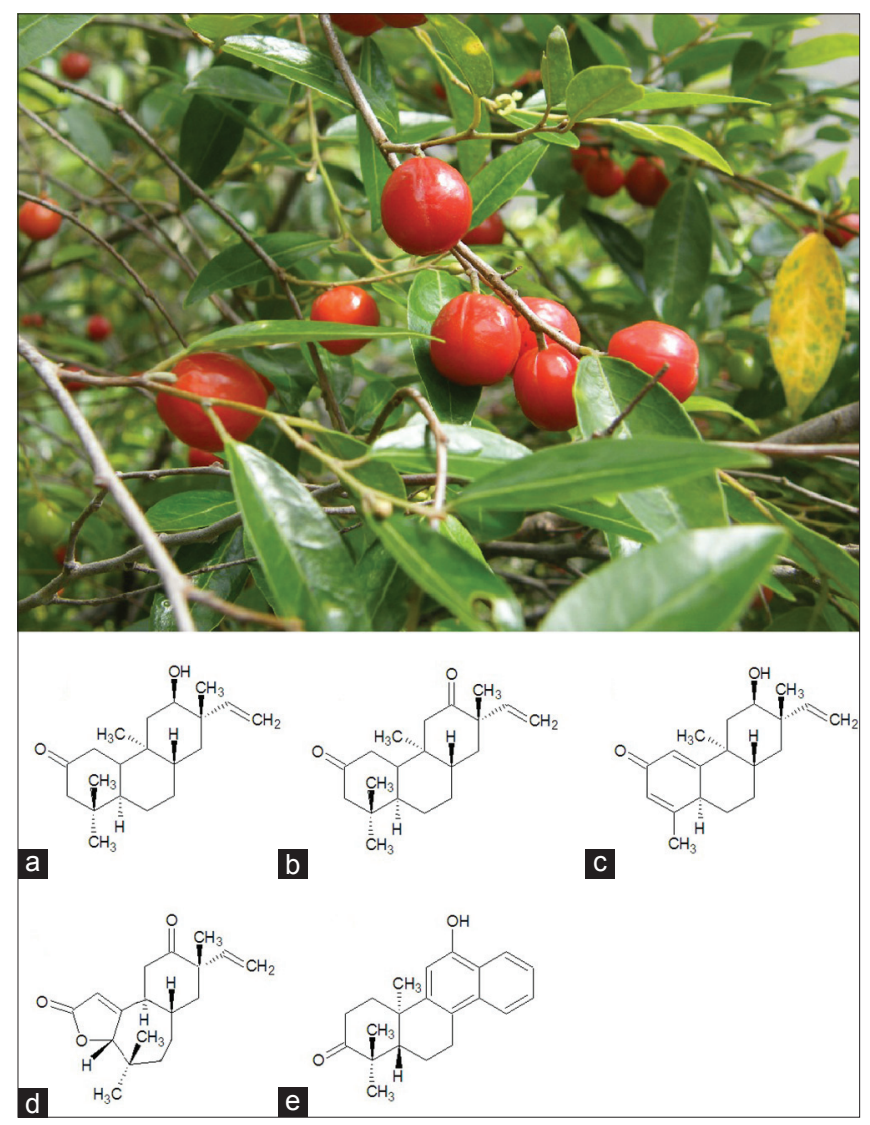

Figure 1: Petalostigma pubescens leaves and fruit (photograph was taken in January 2011 in Toohey Forrest, Australia by Dr lan Cock) and five tricyclic diterpenes present within $P$. pubescens heartwood: (a) 5,9-syn-rosane petalostigmone A, (b) 5,9-syn-rosane petalostigmone $\mathrm{B}$, (c) erythroxylane petalostigmone $\mathrm{C}$, (d) pubescenone, (e) sonderianol 


\section{Qualitative phytochemical studies}

Phytochemical analysis of Petalostigma spp. extracts for the presence of saponins, phenolic compounds, flavonoids, polysteroids, triterpenoids, cardiac glycosides, anthraquinones, tannins and alkaloids was conducted by previously described assays. ${ }^{[16,17]}$

\section{Antibacterial screening}

\section{Test microorganisms}

All microbial strains were obtained from Michelle Mendell and Tarita Morais, Griffith University, Australia. Stock cultures of Aeromonas bydrophila, Alcaligenes feacalis, Bacillus cereus, Citrobacter freundii, Escherichia coli, Klebsiella pneumoniae, Proteus mirabilis, Pseudomonas fluorescens, Salmonella newport, Serratia marcescens, Shigella sonnei, Staphylococcus aureus, Staphylococcus epidermidis and Streptococcus pyogenes were subcultured and maintained in nutrient broth at $4^{\circ} \mathrm{C}$.

\section{Evaluation of antimicrobial activity}

Antimicrobial activity of all plant extracts was determined using a modified disc diffusion method. ${ }^{[18-20]}$ Briefly, $100 \mu \mathrm{l}$ of the test bacteria were grown in $10 \mathrm{ml}$ of fresh nutrient broth until they reached a count of approximately $10^{8}$ cells $/ \mathrm{ml}$ as determined by direct microscopic determination. One hundred microliters of microbial suspension was spread onto nutrient agar plates.

The extracts were tested using 5-mm sterilised filter paper discs. Discs were impregnated with $10 \mu \mathrm{l}$ of the test sample, allowed to dry and placed onto inoculated plates. The plates were allowed to stand at $4^{\circ} \mathrm{C}$ for 2 hours before incubation with the test microbial agents. Plates inoculated with Alcaligenes feacalis, Aeromonas bydrophilia, Bacillus cereus, Citrobacter freundii, Klebsiella pneumoniae, Proteus mirabilis, Pseudomonas fluorescens, Serratia marcescens, were incubated at $30^{\circ} \mathrm{C}$ for 24 hours, then the diameters of the inhibition zones were measured in millimetres. Plates inoculated with E. coli, S. newport, S. sonnei, S. aureus, S. epidermidis and Streptococcus pyogenes were incubated at $37^{\circ} \mathrm{C}$ for 24 hours, then the diameters of the inhibition zones were measured. All measurements were to the closest whole millimetre. Each antimicrobial assay was performed in at least triplicate and mean values were determined. Standard discs of ampicillin $(2 \mu \mathrm{g})$ and chloramphenicol $(10 \mu \mathrm{g})$ were obtained from Oxoid Ltd. and served as positive controls for antimicrobial activity. Filter discs impregnated with $10 \mu \mathrm{l}$ of distilled water or $10 \mu \mathrm{l}$ of $10 \%$ methanol were used as negative controls.

\section{Minimum inhibitory concentration determination}

The minimum inhibitory concentration (MIC) of the Petalostigma spp. extracts were determined by the disc diffusion method across a range of doses. The plant extracts were diluted in deionised water across a concentration range of $5 \mathrm{mg} / \mathrm{ml}$ to $0.1 \mathrm{mg} / \mathrm{ml}$. Discs were impregnated with $10 \mu \mathrm{l}$ of the test dilutions, allowed to dry and placed onto inoculated plates. The assay was performed as outlined above and graphs of the zone of inhibition versus concentration were plotted for each extract. Linear regression was used to calculate the MIC values.

\section{Screen for antiviral bioactivity \\ Viral and bacterial stocks}

MS2 bacteriophage, and F + Amp $+E$. coli used in this study were supplied by Dr. Jatinder Sidhu and Dr. Simon Toze of CSIRO, St. Lucia Qld, Australia. All stock cultures were subcultured and maintained in nutrient broth at $4^{\circ} \mathrm{C}$.

\section{Production of MS2 virus}

$100 \mathrm{ml}$ of nutrient broth (25 g/l) containing ampicillin $(100 \mu \mathrm{g} / \mathrm{ml})$ was inoculated with $1 \mathrm{ml}$ $\mathrm{F}+\mathrm{Amp}+\mathrm{E}$. coli culture and incubated overnight at $37^{\circ} \mathrm{C}$. The following day, flasks containing $30 \mathrm{ml}$ of nutrient broth (containing $100 \mu \mathrm{g} / \mathrm{ml}$ ampicillin) were inoculated with $1 \mathrm{ml}$ of the $\mathrm{F}+\mathrm{Amp}+\mathrm{E}$. coli overnight culture and incubated for 2 hours at $37^{\circ} \mathrm{C}$ and $160 \mathrm{rpm}$. Once bacterial cells had reached log phase, $1 \mathrm{ml}$ of stock MS2 virus (containing approximately $10^{8}$ plaque forming units) was added and incubated overnight at $35^{\circ} \mathrm{C}$. The solution was centrifuged at $4000 \mathrm{rpm}$ for $10 \mathrm{~min}$ and the supernatant was collected and passed through a $22 \mu \mathrm{m}$ Sarstedt filter. All stock and working solutions were stored at $4^{\circ} \mathrm{C}$ until use.

\section{Soft agar overlay}

A soft agar overlay was prepared to a final concentration of $0.7 \% \mathrm{w} / \mathrm{v}$ agar, $1 \% \mathrm{w} / \mathrm{v}$ glucose, $1 \% \mathrm{w} / \mathrm{v} \mathrm{CaCl}_{2}$ solution and $1 \% \mathrm{w} / \mathrm{v} \mathrm{MgSO}_{4}$ and autoclaved at $120^{\circ} \mathrm{C}$ for $20 \mathrm{~min}$. The soft agar overlay was allowed to cool to $65^{\circ} \mathrm{C}$, then nalidixic acid was added to a final concentration of $0.4 \% \mathrm{w} / \mathrm{v}$. The overlay was used immediately for the MS2 plaque inhibition assay described below.

\section{MS2 plaque inhibition assay}

The MS2 plaque assay was performed as previously described. ${ }^{[21]}$ Briefly, $490 \mu \mathrm{l}$ of crude plant extract was inoculated with $10 \mu \mathrm{l}$ of MS2 virus (containing approximately $10^{10}$ plaque forming units $/ \mathrm{ml}$ ) and incubated overnight at $4^{\circ} \mathrm{C}$. The solution was added to $500 \mu \mathrm{l}$ $\mathrm{F}+\mathrm{Amp}+\mathrm{E}$. coli and incubated at $37^{\circ} \mathrm{C}$ for 20 minutes. The bacteria/virus/extract mixture was then added to $3 \mathrm{ml}$ soft agar overlay and immediately poured over pre-made agar plates (2.8\% w/v agar). Plates were allowed to set for $15 \mathrm{~min}$ at room temp, inverted and incubated overnight at $37^{\circ} \mathrm{C}$. The following morning, plaques were counted and a percentage inhibition recorded. Serial dilution was used to determine the antiviral strength of samples where necessary. Nutrient broth and deionized water were 
used as negative controls, while C. sinensis water extract, and UV irradiation (microwave of $10 \mu \mathrm{l}$ virus only for $4 \times 30$ seconds) were used as positive controls.

\section{Toxicity screening}

\section{Reference toxins for biological screening}

Potassium dichromate $\left(\mathrm{K}_{2} \mathrm{Cr}_{2} \mathrm{O}_{7}\right)$ (AR grade, Chem-Supply, Australia) was prepared as a $1.6 \mathrm{mg} / \mathrm{ml}$ solution in distilled water and was serially diluted in synthetic seawater for use in the Artemia franciscana nauplii bioassay. Mevinphos (2-methoxycarbonyl-1-methylvinyl dimethyl phosphate) was obtained from Sigma-Aldrich as a mixture of cis $(76.6 \%)$ and trans $(23.0 \%)$ isomers and prepared as a $4 \mathrm{mg} / \mathrm{ml}$ stock in distilled water. The stock was serially diluted in artificial seawater for use in the bioassay.

\section{Artemia franciscana nauplii toxicity screening}

Toxicity was tested using a modified $A$. franciscana nauplii lethality assay. ${ }^{[0,22]}$ Briefly, $A$. franciscana cysts were obtained from North American Brine Shrimp, LLC, USA (harvested from the Great Salt Lake, Utah). Synthetic seawater was prepared using Reef Salt, AZOO Co., USA. Seawater solutions at $34 \mathrm{~g} / 1$ distilled water were prepared prior to use. $2 \mathrm{~g}$ of $A$. franciscana cysts were incubated in 11 synthetic seawater under artificial light at $25^{\circ} \mathrm{C}, 2000$ Lux with continuous aeration. Hatching commenced within 16-18 h of incubation. Newly hatched $A$. franciscana (nauplii) were used within $10 \mathrm{~h}$ of hatching. Nauplii were separated from the shells and remaining cysts and were concentrated to a suitable density by placing an artificial light at one end of their incubation vessel and the nauplii-rich water closest to the light was removed for biological assays. Four hundred microliters of seawater containing approximately 41 (mean 40.8, $n=180$, SD 16.4) nauplii were added to wells of a 48-well plate and immediately used for bioassay. The plant extracts were diluted to $4 \mathrm{mg} / \mathrm{ml}$ in seawater for toxicity testing, resulting in a $2 \mathrm{mg} / \mathrm{ml}$ concentration in the bioassay. Four hundred microliters of diluted plant extract and the reference toxins were transferred to the wells and incubated at $25 \pm 1{ }^{\circ} \mathrm{C}$ under artificial light (1000 Lux). A negative control $(400-\mu$ l seawater) was run in at least triplicate for each plate. All treatments were performed in at least triplicate. The wells were checked at regular intervals and the number of dead counted. The nauplii were considered moribund if no movement of the appendages was observed within $10 \mathrm{sec}$. After $72 \mathrm{~h}$ all nauplii were sacrificed and counted to determine the total number per well. The $\mathrm{LC}_{50}$ with $95 \%$ confidence limits for each treatment was calculated using probit analysis.

\section{Reverse phase high performance liquid chromatography}

Gradient RP-HPLC was performed at a flow rate of $1 \mathrm{mg} / \mathrm{ml}$ using dual LC-10 AT VP pumps (Shimadzu
HPLC class VP series), a variable wavelength programmable photodiode array detector SPD MIOA VP (Shimadzu), a CTO-IOAS VP column oven (Shimadzu), an SCL-10A VP system controller (Shimadzu) and a Bio-Rad reverse phase $C_{18}$ column $(150 \mathrm{~mm} \times 4.6 \mathrm{~mm})$. The HPLC system was equipped with software class VP series version 6.12 (Shimadzu). The gradient was performed as follows: $5 \mathrm{~min} 0 \%$ methanol, followed by a $10 \mathrm{~min}$ gradient to $5 \%$ methanol. This was followed by a $10 \mathrm{~min}$ gradient to $20 \%$ methanol; 5 min gradient to $100 \%$ methanol; $100 \%$ methanol for $5 \mathrm{~min} ; 5$ min gradient to $0 \%$ methanol. The column temperature was maintained at $24^{\circ} \mathrm{C}$ throughout. A $20-\mu \mathrm{l}$ sample was injected using the autoinjector (Shimadzu). Twenty microliter of deionized water was used as a negative control to produce the baseline curve and zero the machine prior to each experiment.

\section{Gas chromatography-mass spectroscopy (GC-MS)}

GC-MS analysis of bioactive Petalostigma extracts were performed as previously described. ${ }^{[23]}$ Briefly, the extracts were diluted to $1 \mathrm{mg} / \mathrm{ml}$ and $0.5 \mu \mathrm{l}$ was separated on a nonpolar DB5-HT capillary column $(20 \mathrm{~m} \times 0.18 \mathrm{~mm})$ with a $0.1-\mu \mathrm{m}$ film ( $\mathrm{J}$ and $\mathrm{W}$ Scientific) fitted to an AutoSystem XL GC-MS. The injector temperature was $270^{\circ} \mathrm{C}$ and the oven temperature was programmed at an initial temperature of $50^{\circ} \mathrm{C}$ for $1 \mathrm{~min}$, rising at $25^{\circ} \mathrm{C}$ per minute to $160^{\circ} \mathrm{C}$ and maintained at that temperature for $1 \mathrm{~min}$. The temperature was subsequently increased by $10^{\circ} \mathrm{C}$ per min to $300^{\circ} \mathrm{C}$ and maintained at that temperature for a further $4.6 \mathrm{~min}$. The carrier gas was helium at a constant pressure of $5 \mathrm{kPa}$. The GC was directly interfaced with an AutoSystem XL quadrapole mass spectrometer with an interface temperature of $270^{\circ} \mathrm{C}$. Sample ionization was by $70 \mathrm{eV}$ electron impact and was analysed in positive mode. Structural determination was by comparison of mass spectral patterns to ChemSpider data bases.

\section{Statistical analysis}

Data are expressed as the mean \pm SEM of at least three independent experiments. The paired $t$-test was used to calculate statistical significance between control and treated groups with a $P<0.05$ considered to be statistically significant.

\section{RESULTS}

Liquid extraction yields and qualitative phytochemical screening

Extraction of $1 \mathrm{~g}$ of dried plant material with various solvents yielded dried plant extracts ranging from $10 \mathrm{mg}$ to $275 \mathrm{mg}$ [Table 1]. P. trilocilare extracts generally had higher yields of extracted material than P.pubescens extracts and fruit extracts had higher extraction yields than the leaf extracts. 
Table 1: The mass of dried extracted material, the concentration of extracts after resuspension in deionised water and qualitative phytochemical screenings of solvent extractions

\begin{tabular}{|c|c|c|c|c|c|c|c|c|c|c|c|c|c|c|c|}
\hline 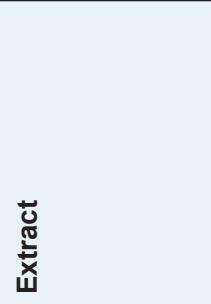 & 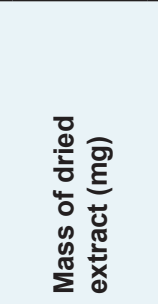 & 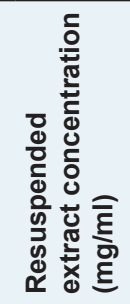 & 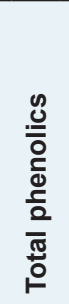 & $\begin{array}{l}\frac{0}{0} \\
\frac{0}{3} \\
0 \\
0 \\
\frac{0}{0} \\
\frac{\pi}{\pi} \\
3\end{array}$ & $\begin{array}{l}\frac{0}{0} \\
\frac{0}{3} \\
0 \\
.5 \\
.5 \\
\frac{0}{0} \\
\frac{\pi}{3}\end{array}$ & $\begin{array}{l}0 \\
\frac{0}{0} \\
\frac{0}{0} \\
0 \\
0 \\
\overline{0} \\
0 \\
0 \\
\frac{\pi}{0} \\
\frac{0}{\pi} \\
0\end{array}$ & 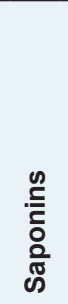 & 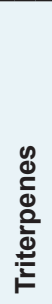 & $\begin{array}{l}\frac{0}{0} \\
\frac{0}{0} \\
\frac{0}{0} \\
\frac{\pi}{0} \\
0\end{array}$ & 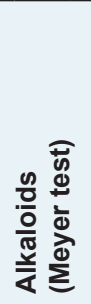 & 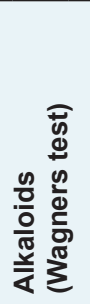 & $\begin{array}{l}\frac{0}{0} \\
\frac{0}{0} \\
\frac{1}{\pi} \\
\frac{\pi}{\pi} \\
\frac{\pi}{4}\end{array}$ & 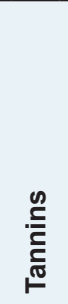 & 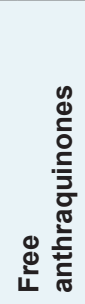 & 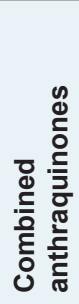 \\
\hline \multicolumn{16}{|l|}{ P. pubescens (L) } \\
\hline Methanol & $90.0 \pm 4.8$ & $9.0 \pm 0.48$ & +++ & +++ & + & ++ & +++ & - & - & - & - & ++ & +++ & ++ & + \\
\hline Water & $87.3 \pm 19.9$ & $8.7 \pm 2.0$ & + & + & - & + & ++ & - & - & - & - & ++ & +++ & ++ & + \\
\hline Ethyl acetate & $23.1 \pm 5.1$ & $2.3 \pm 0.5$ & - & - & - & + & + & - & - & - & - & - & - & + & + \\
\hline Chloroform & $46.5 \pm 11.9$ & $4.7 \pm 1.2$ & - & - & - & - & - & - & - & - & - & - & - & - & - \\
\hline Hexane & $20.3 \pm 4.6$ & $2.0 \pm 0.5$ & + & - & - & - & - & - & - & - & - & - & - & - & - \\
\hline \multicolumn{16}{|l|}{ P. pubescens (F) } \\
\hline Methanol & $154.4 \pm 36.0$ & $15.4 \pm 3.6$ & ++ & ++ & + & + & ++ & - & - & + & + & + & +++ & ++ & ++ \\
\hline Water & $64.8 \pm 6.9$ & $6.5 \pm 0.7$ & + & + & - & +++ & + & - & - & - & - & ++ & +++ & ++ & ++ \\
\hline Ethyl acetate & $24.3 \pm 5.3$ & $2.4 \pm 0.5$ & + & + & - & + & + & - & - & - & - & ++ & ++ & - & - \\
\hline Chloroform & $79.7 \pm 13.7$ & $8.0 \pm 1.4$ & - & - & - & - & - & - & - & - & - & - & - & - & - \\
\hline Hexane & $10.6 \pm 1.7$ & $1.1 \pm 0.2$ & - & - & - & - & - & - & - & - & - & - & - & - & - \\
\hline \multicolumn{16}{|l|}{ P. triloculare $(\mathrm{L})$} \\
\hline Methanol & $123.2 \pm 14.8$ & $12.3 \pm 1.5$ & +++ & +++ & + & ++ & +++ & - & - & - & - & ++ & +++ & ++ & + \\
\hline Water & $111.6 \pm 24.1$ & $11.2 \pm 2.4$ & + & + & - & + & ++ & - & - & - & - & ++ & +++ & ++ & + \\
\hline Ethyl acetate & $40.3 \pm 4.2$ & $4.0 \pm 0.4$ & - & - & - & + & + & - & - & - & - & - & - & + & + \\
\hline Chloroform & $92.3 \pm 18.8$ & $9.2 \pm 1.9$ & - & - & - & - & - & - & - & - & - & - & - & - & - \\
\hline Hexane & $36.1 \pm 7.7$ & $3.6 \pm 0.8$ & + & - & - & - & - & - & - & - & - & - & - & - & - \\
\hline \multicolumn{16}{|l|}{ P. trilocilare $(\mathrm{F})$} \\
\hline Methanol & $272.7 \pm 31.8$ & $27.3 \pm 3.2$ & ++ & ++ & + & + & ++ & - & - & + & + & + & +++ & ++ & ++ \\
\hline Water & $86.6 \pm 16.4$ & $8.7 \pm 1.6$ & + & + & - & +++ & + & - & - & - & - & ++ & +++ & ++ & ++ \\
\hline Ethyl acetate & $47.7 \pm 6.0$ & $4.8 \pm 0.6$ & + & + & - & + & + & - & - & - & - & ++ & ++ & - & - \\
\hline Chloroform & $105.7 \pm 18.3$ & $10.6 \pm 1.8$ & - & - & - & - & - & - & - & - & - & - & - & - & - \\
\hline Hexane & $22.3 \pm 5.2$ & $2.2 \pm 0.5$ & - & - & - & - & - & - & - & - & - & - & - & - & - \\
\hline
\end{tabular}

(L) indicates leaf extract, (F) indicates fruit extract, +++ indicates a large response, ++ indicates a moderate response, + indicates a minor response, - indicates no response in the assay

Methanol, deionised water and chloroform gave relatively high yields of dried extracted material (up to approximately $275 \mathrm{mg}$ for P. trilocilare fruit methanolic extract) while hexane extracted the lowest mass (as low as approximately $10 \mathrm{mg}$ for $P$. pubescens fruit hexane extract). The dried extracts were resuspended in $10 \mathrm{ml}$ of deionised water resulting in the extract concentrations shown in Table 1.

Phytochemical studies [Table 1] show that methanol extracted the widest range and largest amount of phytochemicals in this study. The methanol extracts of both leaves and fruit for both plants showed moderate to high levels of water-soluble phenolics, saponins and tannins, with lower levels of flavonoids and cardiac glycosides present. Similar classes of phytochemicals were detected in the water and ethyl acetate extracts, although generally at lower levels. Alkaloids were only detected in the methanol extract of the fruits of both plants, and only at low levels. No alkaloids were detected in extracts using any other solvent, or in the leaf extracts. The chloroform and hexane extracts showed only low levels of any class of extracted phytochemicals tested.

\section{Antibacterial activity}

Aliquots $(10 \mu \mathrm{l})$ of dilutions of each extract were tested in the disc diffusion assay against 14 bacteria and the MIC's were determined [Table 2]. The methanol, water and ethyl acetate extracts all displayed broad-spectrum antibacterial activity, inhibiting the growth of $\geq 7$ of the 14 bacteria tested. The number of bacterial species inhibited was higher for the methanol and ethyl acetate leaf extracts (10 out of 14 bacteria tested; $71 \%$ ) than in the methanol and ethyl acetate fruit extracts ( 9 out of 14 bacteria tested; 64\%). Similarly, the water leaf extracts inhibited the growth of 8 of the 14 bacteria tested (57\%) compared to 7 bacteria inhibited (50\%) for the water fruit extracts. No inhibitory activity was evident for any of the chloroform or hexane extracts at the doses tested. The methanol, water and ethyl acetate extracts were all potent inhibitors of antibacterial growth, with 


\begin{tabular}{|c|c|c|c|c|c|c|c|c|c|c|c|c|c|c|}
\hline & \multicolumn{10}{|c|}{ Gram-negative bacteria } & \multicolumn{4}{|c|}{ Gram-positive bacteria } \\
\hline & \multicolumn{10}{|c|}{ Rods } & Rods & \multicolumn{3}{|c|}{ Cocci } \\
\hline & 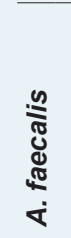 & 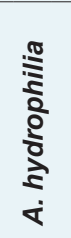 & $\begin{array}{l}\bar{\delta} \\
\overline{0} \\
\dot{0} \\
ن\end{array}$ & $\begin{array}{l}\overline{\text { ò }} \\
\text { uं }\end{array}$ & 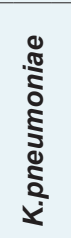 & 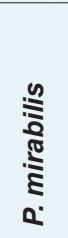 & 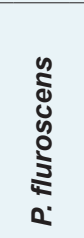 & 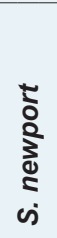 & 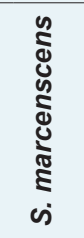 & 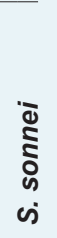 & 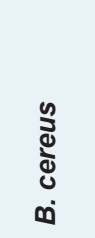 & 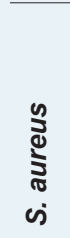 & 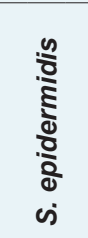 & 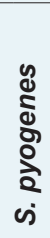 \\
\hline \multicolumn{15}{|c|}{ P. pubescens (leaf) } \\
\hline Methanol & 0.7 & 1.2 & 0.6 & - & 1 & 0.3 & 0.5 & - & 1.4 & - & 0.4 & 1.2 & 0.3 & - \\
\hline Water & 4.5 & 1.9 & - & - & 1.2 & 4.2 & 10.2 & - & 11 & - & 3.8 & 3.1 & - & - \\
\hline Ethyl acetate & 0.4 & 0.4 & 0.2 & - & 0.3 & 0.2 & 0.4 & - & 0.8 & - & 0.4 & 0.8 & 0.2 & - \\
\hline Chloroform & - & - & - & - & - & - & - & - & - & - & - & - & - & - \\
\hline Hexane & - & - & - & - & - & - & - & - & - & - & - & - & - & - \\
\hline \multicolumn{15}{|c|}{ P. pubescens (fruit) } \\
\hline Methanol & - & 2.4 & 1.1 & - & 1 & 1.3 & 0.8 & - & 1.9 & - & 2.3 & 1.6 & 0.8 & - \\
\hline Water & - & 4.2 & - & - & 9.5 & 1.7 & 4.1 & - & 11.1 & - & 11.3 & 11.2 & - & - \\
\hline Ethyl acetate & - & 0.4 & 0.4 & - & 0.1 & 0.6 & 0.4 & - & 10.4 & - & 1.1 & 0.9 & 0.4 & - \\
\hline Chloroform & - & - & - & - & - & - & - & - & - & - & - & - & - & - \\
\hline Hexane & - & - & - & - & - & - & - & - & - & - & - & - & - & - \\
\hline \multicolumn{15}{|l|}{ P. triculare (leaf) } \\
\hline Methanol & 0.6 & 1.1 & 0.6 & - & 1 & 0.3 & 0.5 & - & 1.5 & - & 0.4 & 1.3 & 0.3 & - \\
\hline Water & 4.7 & 1.8 & - & - & 1.1 & 3.7 & 9.8 & - & 10.3 & - & 3.4 & 3.3 & - & - \\
\hline Ethyl acetate & 0.5 & 0.4 & 0.2 & - & 0.3 & 0.2 & 0.4 & - & 0.8 & - & 0.4 & 0.8 & 0.2 & - \\
\hline Chloroform & - & - & - & - & - & - & - & - & - & - & - & - & - & - \\
\hline Hexane & - & - & - & - & - & - & - & - & - & - & - & - & - & - \\
\hline \multicolumn{15}{|l|}{ P. triculare (fruit) } \\
\hline Methanol & - & 2.1 & 1 & - & 1 & 0.7 & 0.8 & - & 2.1 & - & 0.7 & 1.4 & 1.2 & - \\
\hline Water & - & 2.5 & - & - & 9.4 & 0.5 & 3.8 & - & 10.4 & - & 4.8 & 8.5 & - & - \\
\hline Ethyl acetate & - & 0.2 & 0.2 & - & 0.1 & 0.2 & 0.3 & - & 0.7 & - & 0.4 & 0.7 & 0.1 & - \\
\hline Chloroform & - & - & - & - & - & - & - & - & - & - & - & - & - & - \\
\hline Hexane & - & - & - & - & - & - & - & - & - & - & - & - & - & - \\
\hline
\end{tabular}

Numbers indicate the mean MIC values of at least triplicate determinations. - indicates no growth inhibition

MIC values generally $<10 \mu \mathrm{g} / \mathrm{ml}$. Ethyl acetate extracts were particularly potent, achieving MIC values less than $1 \mu \mathrm{g} / \mathrm{ml}$ for nearly every bacterial species for which they displayed antibacterial activity.

The methanol and ethyl acetate extracts inhibited the growth of Gram-positive and Gram-negative approximately equally. Methanolic and ethyl acetate leaf extracts of both species inhibited the growth of 7 of the Gram-negative bacteria tested (70\%) compared with 3 of the 4 Gram-positive bacteria tested (75\%). Similarly, P. pubescens and P. triloculare methanol and ethyl acetate fruit extracts inhibited the growth of 6 of the Gram-negative bacteria tested $(60 \%)$ and 3 Gram-positive bacteria $(75 \%)$. The P. pubescens and P. triloculare water leaf and fruit extracts inhibited the growth of $6(60 \%)$ and $5(50 \%)$ of the Gram-negative bacteria tested respectively. Similarly, they inhibited $2(50 \%)$ of the Gram-positive bacteria tested.

\section{Antiviral activity}

Figure 2 shows the formation of MS2 bacteriophage plaques in the presence of the Petalostigma extracts $(1000 \mu \mathrm{g} / \mathrm{ml})$ or the positive and negative controls as a $\%$ of control plaque formation. The methanol, water and ethyl acetate extracts of the leaf and fruit of both Petalostigma species displayed antiviral activity when tested in the MS2 plaque bioassay. The water and ethyl acetate extracts were particularly effective at inhibiting MS2 plaque formation, inhibiting approximately $85-97 \%$ (for the water extracts) and $100 \pm 0 \%$ (for ethyl acetate extracts) of the plaque formation, respectively. The methanol extracts were also effective, inhibiting between $27 \%$ (PTLM) and 49\% (PPFM) of plaque formation. In contrast, the C. sinesis control inhibited approximately $91 \%$ of bacteriophage plaque formation.

The $P$. pubescens and $P$. triloculare extracts were further tested over a range of concentrations to determine the minimum concentration capable of inhibiting $100 \%$ of plaque formation $\left(\mathrm{PI}_{100}\right)$ and the minimum concentration capable 
of inhibiting $50 \%$ of plaque formation $\left(\mathrm{PI}_{50}\right)$ [Table 3]. The minimum dosage of the positive control (C. sinensis leaf extract) capable of totally blocking $100 \%$ MS2 plaque formation $\left(\mathrm{PI}_{100}\right.$ ) was $2960 \mu \mathrm{g} / \mathrm{ml}$ while the minimum concentration of $C$. sinensis leaf extract capable of blocking $50 \%$ of MS2 plaque formation $\left(\mathrm{PI}_{50}\right.$ ) was $590 \mu \mathrm{g} / \mathrm{ml}$. All of the Petalostigma water and ethyl acetate extracts were more effective antiviral agents than the $C$. sinensis control as determined by their lower $\mathrm{PI}_{50}$ values. The water extracts of the fruit proved the most effective, with a $\mathrm{PI}_{50}$ values of $220 \mu \mathrm{g} / \mathrm{ml}$ and $180 \mu \mathrm{g} / \mathrm{ml}$ for the $P$. pubescens and $P$. triloculare ethyl acetate extracts respectively. The order of effectiveness of MS2 plaque reduction was $P$. triloculare fruit water extract $>P$. pubescen fruit water extract $>P$. triloculare fruit ethyl acetate extract $>P$. pubescen fruit ethyl acetate extract $>P$. pubescen leaf ethyl acetate extract $>P$. pubescen leaf water extract $>P$. triloculare leaf ethyl acetate extract $>P$. triloculare leaf water extract $>C$. sinensis extract $>P$. pubescens fruit methanol extract $>P$. triloculare fruit methanol extract $>P$. pubescen leaf methanol extract $>P$. triloculare leaf methanol extract.

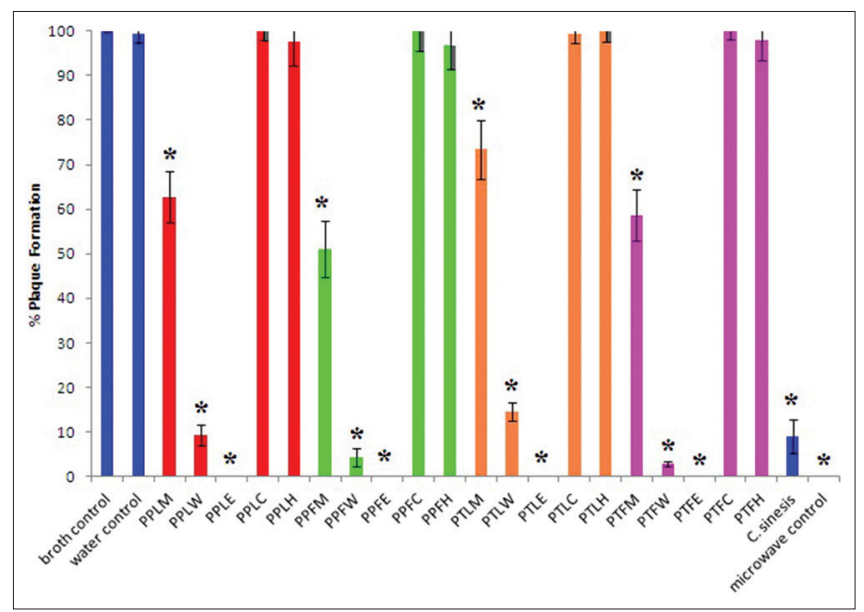

Figure 2: MS2 plaque formation in a E. coli lawn expressed as \% of control plaque formation following incubation of the MS2 with nutrient broth (negative control); deionized water (negative control); (PPLM) $P$. pubescens leaf methanol extract; (PPLW) P. pubescens leaf water extract; (PPLE) P. pubescens leaf ethyl acetate extract; (PPLC) $P$. pubescens leaf chloroform extract; (PPLH) P. pubescens leaf hexane extract; (PPFM) P. pubescens fruit methanol extract; (PPFW) $P$. pubescens fruit water extract; (PPFE) P. pubescens fruit ethyl acetate extract; (PPFC) P. pubescens fruit chloroform extract; (PPFH) $P$. pubescens fruit hexane extract; (PTLM) P. triloculare leaf methanol extract; (PTLW) P. triloculare leaf water extract; (PTLE) P. triloculare leaf ethyl acetate extract; (PTLC) $P$. triloculare leaf chloroform extract; (PTLH) P. triloculare leaf hexane extract; (PTFM) P. triloculare fruit methanol extract; (PTFW) P. triloculare fruit water extract; (PTFE) $P$. triloculare fruit ethyl acetate extract; (PTFC) $P$. triloculare fruit chloroform extract; (PTFH) P. triloculare fruit hexane extract; $C$. sinensis leaf water extract $(1000 \mu \mathrm{g} / \mathrm{ml})$; nutrient agar and microwave irradiated MS2 phage (positive control). All Petalostigma extracts were tested at $1000 \mu \mathrm{g} / \mathrm{ml}$. Results are reported as the mean of triplicate assays \pm SEM. * indicates a statistically significant difference to the negative control $(P<0.05)$

\section{Quantification of toxicity}

$P$. pubescens and P. triloculare leaf and fruit extracts were serially diluted in artificial seawater for toxicity testing in the Artemia nauplii lethality bioassay. For comparison, the reference toxins potassium dichromate and Mevinphos were also tested in the bioassay. Table 4 shows the extract or control toxin concentrations required to achieve 50\% mortality $\left(\mathrm{LC}_{50}\right)$ at various times. Potassium dichromate and Mevinphos (reference toxins) were rapid in their onset of mortality. Both reference toxins induced mortality within the first 3 hours of exposure while greater than 12 hours was required for mortality induction by the Petalostigma extracts (results not shown). As toxicity of crude plant extracts has previously been defined as 24 or $48 \mathrm{~h} \mathrm{LC} \mathrm{L}_{50}$ values $<1000 \mu \mathrm{g} / \mathrm{ml},{ }^{[24]}$ the measured $\mathrm{LC}_{50}$ values indicate that all Petalostigma extracts were non-toxic or of low toxicity. Only the P. triloculare leaf and fruit ethyl acetate extracts displayed $\mathrm{LC}_{50}$ values below $1000 \mu \mathrm{g} / \mathrm{ml}$ at 24 and/or $48 \mathrm{~h}$ and even these $\mathrm{LC}_{50}$ values indicate low toxicity. All Petalostigma methanolic extracts also induced mortality above that of the seawater control, although their

\begin{tabular}{|c|c|c|}
\hline Extract & $\mathrm{PI}_{100}$ & $\mathrm{PI}_{50}$ \\
\hline \multicolumn{3}{|c|}{ P. pubescens (leaf) } \\
\hline Methanol & 2160 & 1230 \\
\hline Water & 1560 & 390 \\
\hline Ethyl acetate & 760 & 350 \\
\hline Chloroform & - & - \\
\hline Hexane & - & - \\
\hline \multicolumn{3}{|c|}{ P. pubescens (fruit) } \\
\hline Methanol & 1610 & 1040 \\
\hline Water & 1480 & 220 \\
\hline Ethyl acetate & 740 & 340 \\
\hline Chloroform & - & - \\
\hline Hexane & - & - \\
\hline \multicolumn{3}{|c|}{ P. triloculare (leaf) } \\
\hline Methanol & 2510 & 1630 \\
\hline Water & 1780 & 570 \\
\hline Ethyl acetate & 840 & 470 \\
\hline Chloroform & - & - \\
\hline Hexane & - & - \\
\hline \multicolumn{3}{|c|}{ P. triloculare (fruit) } \\
\hline Methanol & 1720 & 1070 \\
\hline Water & 1250 & 180 \\
\hline Ethyl acetate & 680 & 290 \\
\hline Chloroform & - & - \\
\hline Hexane & - & - \\
\hline \multicolumn{3}{|l|}{ Controls } \\
\hline Broth control & - & - \\
\hline Water control & - & - \\
\hline C. sinensis & 2960 & 490 \\
\hline
\end{tabular}

Numbers indicate the means of at least triplicate determinations. - indicates no plaque reduction 


\begin{tabular}{|c|c|c|c|}
\hline \multirow{2}{*}{ Extract } & \multicolumn{3}{|c|}{$\mathrm{LC}_{50}(\mu \mathrm{g} / \mathrm{ml})$} \\
\hline & 24 hours & 48 hours & 72 hours \\
\hline \multicolumn{4}{|l|}{ P. pubescens (leaf) } \\
\hline Methanol & 1622 & 1278 & 375 \\
\hline Water & - & - & - \\
\hline Ethyl acetate & 1568 & 1240 & 385 \\
\hline Chloroform & - & - & - \\
\hline Hexane & - & - & - \\
\hline \multicolumn{4}{|l|}{ P. pubescens (fruit) } \\
\hline Methanol & - & - & 1500 \\
\hline Water & - & - & - \\
\hline Ethyl acetate & 1523 & 1281 & 373 \\
\hline Chloroform & - & - & - \\
\hline Hexane & - & - & - \\
\hline \multicolumn{4}{|l|}{ P. triloculare (leaf) } \\
\hline Methanol & - & 1245 & 608 \\
\hline Water & - & - & - \\
\hline Ethyl acetate & 814 & 685 & 312 \\
\hline Chloroform & - & - & - \\
\hline Hexane & - & - & - \\
\hline \multicolumn{4}{|l|}{ P. triloculare (fruit) } \\
\hline Methanol & - & 1636 & 654 \\
\hline Water & - & - & - \\
\hline Ethyl acetate & 1650 & 834 & 188 \\
\hline Chloroform & - & - & - \\
\hline Hexane & - & - & - \\
\hline \multicolumn{4}{|l|}{ Controls } \\
\hline Mevinphos & 1346 & 505 & 104 \\
\hline Potassium dichromate & 264 & 36 & 14 \\
\hline Seawater control & - & - & - \\
\hline
\end{tabular}

- denotes values that were not obtained as $\geq 50 \%$ mortality was not obtained at this time point

$\mathrm{LC}_{50}$ values indicate that they are nontoxic. The water, chloroform and hexane extracts not induce mortality above that of the seawater controls at any time point measured and are therefore considered nontoxic.

\section{RP-HPLC analysis of extracts displaying antimicrobial activity}

As the $P$. triloculare extracts displayed the greatest antibacterial activity, the methanol and ethyl acetate leaf and fruit extracts of this plant were further analysed by RP-HPLC. The P. triloculare fruit methanol extract chromatogram [Figure $3 \mathrm{~b}$ ] revealed numerous overlapping peaks, particularly in the very early stages of the chromatogram corresponding to the elution of polar compounds. The $P$. triloculare leaf methanol extract [Figure 3a] also had large amounts of polar material eluting early in the chromatogram. However, a large peak later in the chromatogram indicates the broad spread of polarities of the compounds in the leaf methanol extract. Similarly, the $P$. triloculare ethyl acetate leaf extract [Figure 3c] and $P$. triloculare ethyl acetate fruit extract [Figure $3 \mathrm{~d}]$ also revealed a broad spread of compound polarities. As the ethyl acetate extracts contained much less extracted material yet still retained the same degree of bioactivity, the $P$. triloculare ethyl acetate extracts were deemed suitable for further analysis by GC-MS. Furthermore, the ethyl acetate extracts also displayed much greater antiviral activity, making them of interest for further study.

\section{GC-MS analysis of the $P$. trilloculore ethyl acetate} extracts

Gas chromatography of the ethyl acetate extract [Figure 4] resulted in the separation of 11 main peaks for the $P$. triloculore ethyl acetate leaf extract and 9 main peaks for the P. triloculore ethyl acetate fruit extract. As fewer peaks were evident for the fruit extract gas chromatogram yet this extract had stronger antibacterial and antiviral bioactivities, the $P$. triloculore ethyl acetate fruit extract peaks were further analysed by MS [Figure 5]. Structural identification was achieved for all 9 of the main compound peaks detected in the $P$. triloculore ethyl acetate fruit extract. The major peak from the gas chromatogram had a retention time of $3.22 \mathrm{~min}$. MS analysis [Figure $5 \mathrm{~d}$ ] determined the mass of this compound to be 142 and the empirical formula to be $\mathrm{C}_{10} \mathrm{H}_{22}$. A comparison with MS data bank ionization patterns showed similarity with the 10 carbon hydrocarbon decane. Another major peak with a retention time of $5.43 \mathrm{~min}$ [Figure $5 \mathrm{~h}$ ] was determined to have a mass of 126 and the empirical formula $\mathrm{C}_{6} \mathrm{H}_{6} \mathrm{O}_{3}$. A comparison with MS data bank ionisation patterns showed similarity with 1, 2, 3-benzenetriol (pyrogallol). Other compounds in the extract were determined to be acetic acid (retention time 1.14; Figure 5a), 2,2-dimethoxybutane (retention time $1.57 \mathrm{~min}$; Figure 5b), 4-methyl-1,3-dioxane (retention time 2.17 min; Figure 4c) and the straight chain hydrocarbon unadecane (retention time 3.88 min; Figure 5e). 2-furanmethanol (retention time 3.97; Figure 4f), 1,2-benzenediol (catechol) (retention time 4.43; Figure 5g) and benzoic acid (p-salicyclic acid) (retention time 6.11; Figure 5i) were also determined to be present in the $P$. triloculore ethyl acetate fruit extract.

\section{DISCUSSION}

The current study reports on the antimicrobial and antiviral activities of various Petalostigma leaf and fruit extracts, and on their toxicity. The ability of $P$. pubescens and $P$. triloculore extracts to inhibit the growth of both Gram-positive and Gram-negative bacteria is in agreement with previous reports of the antibacterial activity of other 


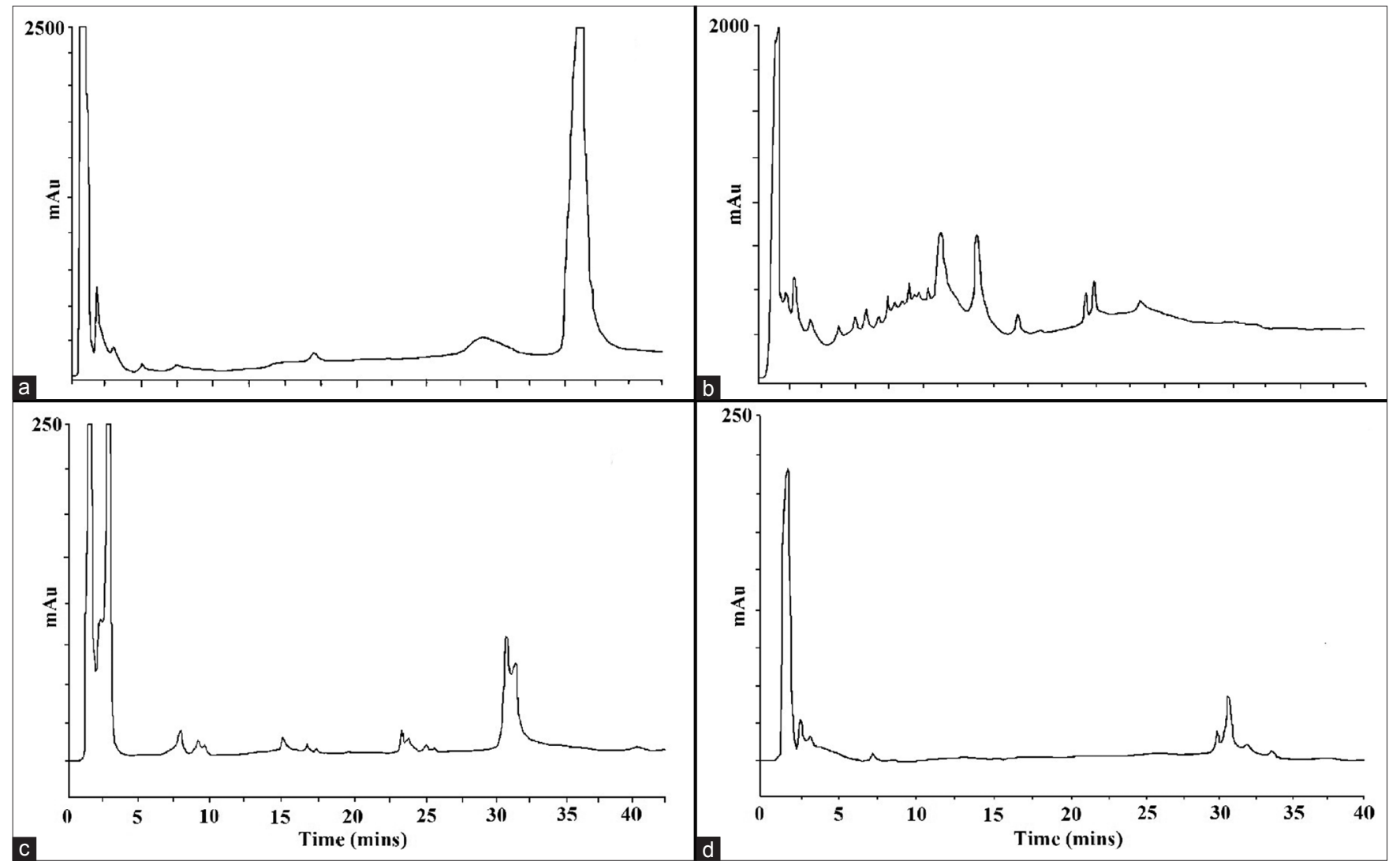

Figure 3: RP-HPLC chromatogram of $20 \mu$ injections of (a) P. triloculore methanol leaf extract, (b) P. triloculore methanol fruit exract, (c) $P$. triloculore ethyl acetate leaf extract, (b) $P$. triloculore ethyl acetate fruit exract. Extracts were dried and resuspended in deionized water. Absorbance was recorded at $210 \mathrm{~nm}$ and chromatography conditions were as described in the methods section
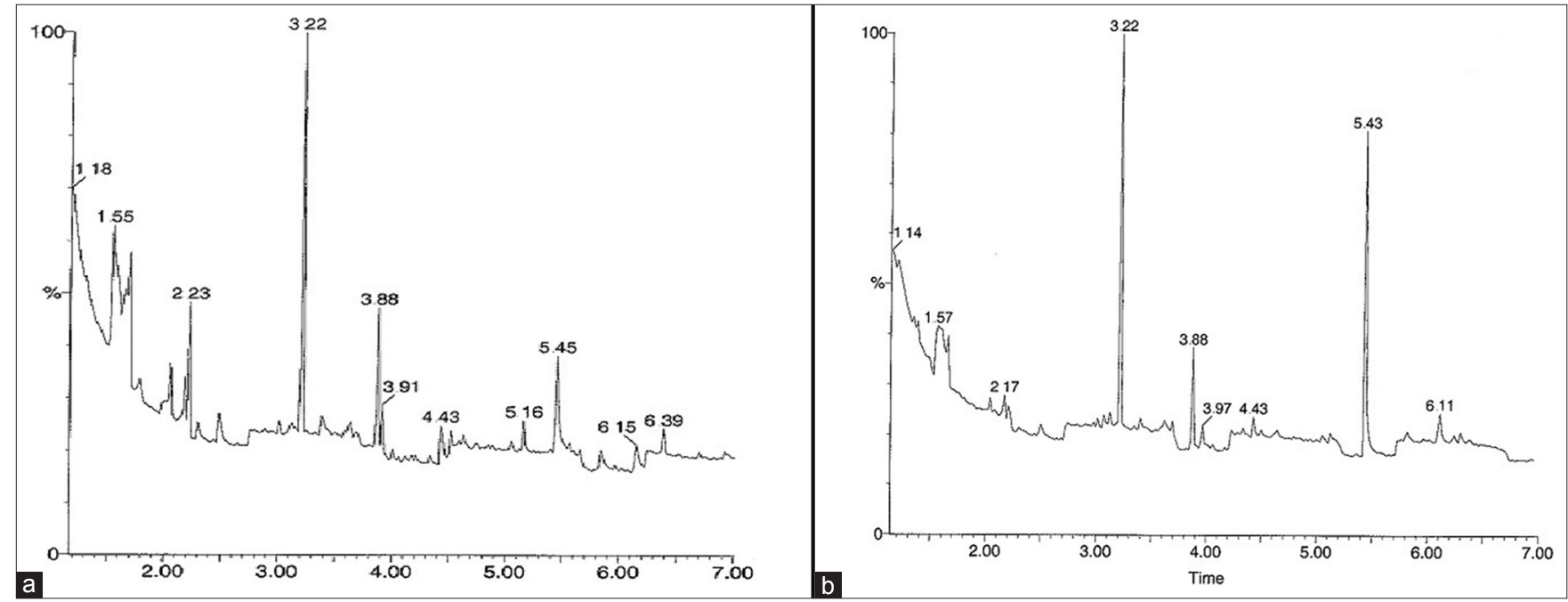

Figure 4: Gas chromatogram of $0.5 \mu \mathrm{L}$ injections of (a) $P$. triloculore ethyl acetate leaf extract and (b) $P$. triloculore ethyl acetate fruit exract. The extracts were dried and resuspended in methanol. Chromatography conditions were as described in the methods section

Australian native plants that have a history of medicinal usage by Australian Aborigines. The antiseptic properties of the Eucalypts, ${ }^{[25]}$ Leptospermums ${ }^{[8,26]}$ and Melaleucas ${ }^{[27]}$ have been extensively studied and shown to inhibit the growth of a wide variety of bacteria. The current study shows Gram-positive and Gram-negative bacteria to be equally susceptible to $P$. pubescens and $P$. triloculore extracts. This is in contrast to previous studies which have reported a greater susceptibility of Gram-positive bacteria toward solvent extracts for South American, ${ }^{[28]}$ African ${ }^{[29]}$ and Australian ${ }^{[30]}$ plant extracts. Results within this laboratory ${ }^{[8]}$ have also confirmed the greater susceptibility 


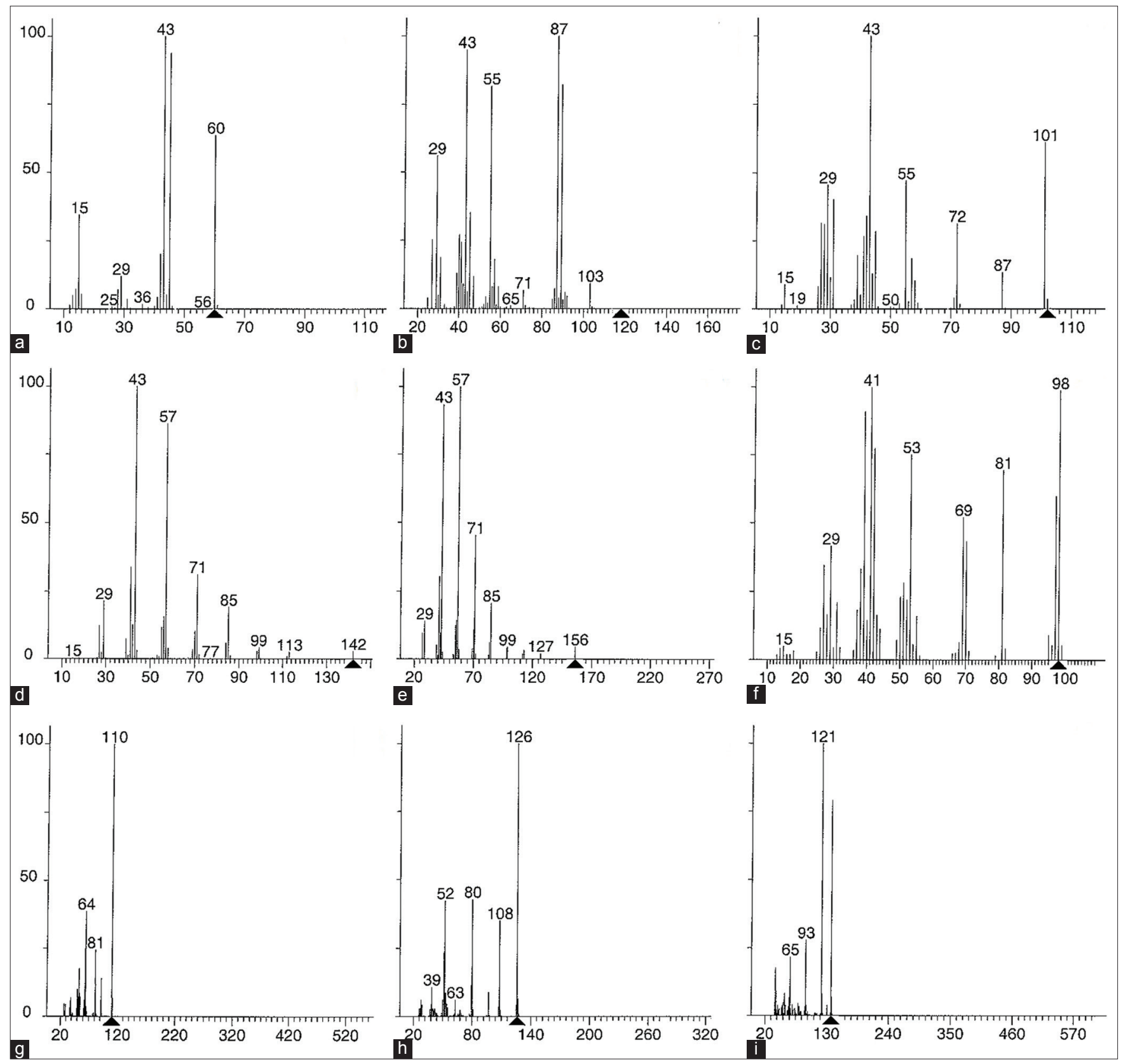

Figure 5: Mass spectra of $P$. triloculore ethyl acetate fruit extract peaks from GC separation. The spectra correspond to peaks from the GC chromatogram with retention times of (a) $1.14 \mathrm{~min}$, (b) $1.57 \mathrm{~min}$, (c) $2.17 \mathrm{~min}$, (d) $3.22 \mathrm{~min}$, (e) $3.88 \mathrm{~min}$, (f) $3.97 \mathrm{~min}$, (g) $4.43 \mathrm{~min}$, (h) $5.43 \mathrm{~min}$, (i) $6.11 \mathrm{~min}$

of Gram-positive bacteria toward other Australian plant extracts.

The methanol, water and ethyl acetate solvent extracts also displayed antiviral activity toward the RNA virus MS2 bacteriophage. While no previous reports of antiviral activity of Petalostigma extracts were found, previous studies have reported antiviral activity of extracts of another Australian species of Euphorbiaceae (Euphorbia australis) toward the DNA virus cyclomeglovirus (CMV). ${ }^{[31]}$ Interestingly, no antiviral activity toward the RNA viruses tested in the earlier study (Ross River virus and polio virus type 1) was reported. Neither the current study nor the earlier study examined the mechanism of antiviral activity. The extract may be acting by direct viral inactivation, or by disrupting one or more stages of viral replication (cellular attachment and penetration, viral uncoating, reverse transcription of viral RNA (in the case of RNA viruses), viral nucleic acid or protein synthesis, viral assembly and release). Further studies are required to determine the antiviral mechanism of the Petalostigma extracts. Furthermore, while the current studies have detected 
antiviral activity toward MS2 bacteriophage and the earlier study ${ }^{[31]}$ has shown anti-CMV activity, the antiviral specificity is yet to be determined toward other viruses of medicinal importance. Future studies need to rigorously test Petalostigma extracts against a wider panel of viruses to determine their medicinal potential.

The findings reported here also demonstrate that none of the P. pubescens and P. triloculore extracts displayed significant toxicity toward $A$. franciscana. Indeed, only the $P$. triloculare leaf and fruit ethyl acetate extracts displayed $\mathrm{LC}_{50}$ values below $1000 \mu \mathrm{g} / \mathrm{ml}$ at $24 \mathrm{and} /$ or $48 \mathrm{~h}$, and even these $\mathrm{LC}_{50}$ values indicate low toxicity. While still classified as lowly toxic, it is evident that the $P$. triloculore ethyl acetate leaf extract did induce mortality above that of the seawater control at $24 \mathrm{~h}$. Therefore, further toxicity studies against human cell lines are warranted to determine the suitability of these $P$. triloculore extracts for medicinal purposes as antimicrobial agents.

Of the compounds detected by GC-MS in the bioactive P. triloculore ethyl acetate fruit extract, several have been reported to have medicinally important bioactivities. Benzoic acid and its derivatives have previously been used in the treatment of fungal disorders including tinea, ringworm and athletes foot. ${ }^{[32,33]}$ They were also used as expectorants, analgesics and antiseptics until the early part of the $20^{\text {th }}$ century. ${ }^{[32,34]}$ Furthermore, sodium benzoate (a soluble benzoic acid salt) is used as a common antimicrobial preservative in foods, although it usage is limited to $\leq 0.1 \%$ due to its toxicity. ${ }^{[32,35]}$ Similarly, the benzene alcohols detected in the P. triloculore ethyl acetate fruit extract (1,2-benzenediol (catechol) and 1,2,3-benzenetriol (pyrogallol) also have documented antiseptic properties. ${ }^{[32]}$ They are also powerful reducing agents and therefore have potential applications in protection against oxidative stress. Furthermore, catechol is also a component of some pesticides and a precursor for several pharmaceuticals.

Several other compounds detected in the P. triloculore ethyl acetate fruit extract are toxic and may therefore contribute to the limited toxicity reported in this extract. The unbranched (decane, unadecane) paraffins detected in this study have previously been reported to be toxic. ${ }^{[3]}$ The branched ether 2,2-dimethoxybutane has also been shown to be toxic. Similarly, acetic acid has previously been shown in our laboratory to induce mortality in $A$. franciscana nauplii and is routinely used to induce mortality in the assay prior to total nauplii counts. ${ }^{[37]}$

Also of interest is the 2-furanmethanol detected in the P. triloculore ethyl acetate fruit extract. Many furans have been shown to have strong bacterial growth inhibitory activity. Furfural (an oxidised form of 2-furanmethanol) has potent antibacterial activity, inhibiting the growth of some microorganisms at concentrations as low as $1 \mathrm{mM} .^{[38]}$ 2-furanmethanol also has demonstrated antibacterial activity against bacteria, ${ }^{[38]}$ albeit at slightly higher concentrations than those reported for furfural. Various other furan derivatives were also been shown to be good antibacterial agents. ${ }^{[39]}$ No reports were found of antiviral activity of furan compounds, except as components of substituted nucleosides to block reverse transcription of RNA viruses. ${ }^{[40]}$ This study also reported that the presence of the ribo-sugar moiety was of absolute importance for the antiviral activity of the substituted nucleosides, indicating that the antiviral activity of the P. triloculore ethyl acetate fruit is likely to be due to components other than 2-furanmethanol.

The phytochemical 4-methyl-1,3-dioxane detected in P. triloculore ethyl acetate fruit extract may also contribute to the antibacterial and antiviral activity reported in this study. A number of dioxane ${ }^{[41]}$ and dioxolane ${ }^{[42]}$ compounds have previously been shown to have good antibacterial and antifungal activities. Furthermore, several dioxane compounds have been reported to have potent antiviral activities, inhibiting Sindbis virus at concentrations as low as $40 \mu \mathrm{M} \cdot{ }^{[43]}$ It is believed that the dioxane-based antiviral agents tested against Sindbis virus blocked virus production by targeting the hydrophobic-binding pocket of the capsid protein. While no reports were found of antiviral activity of 4-methyl-1,3-dioxane, it is possible that it may act in a similar manner in the MS2 phage assay, blocking virus production, although this is yet to be tested.

\section{CONCLUSIONS}

The results of this study partially validate the traditional Australian Aboriginal usage of Petalostigma species to treat bacterial and viral diseases and indicate that $P$. pubescens and $P$. triloculore are worthy of further study. Further evaluation of the antibacterial and antiviral properties of these extracts against a more extensive panel of microbial agents is warranted. Likewise, purification and examination of the mechanisms of action of these agents is required. While the extracts examined in this report are promising as antibacterial and antiviral agents, caution is needed before these compounds can be applied to medicinal purposes. In particular, further toxicity studies using human cell lines are needed to verify the suitability of these extracts for these purposes.

\section{ACKNOWLEDGMENTS}

The MS2 bacteriophage and the F + and F-Amp + E. coli used in these studies were supplied by Dr. Jatinder Sidhu and Dr. Simon Toze of CSIRO, St Lucia Qld, Australia. Financial support for 
this work was provided by School of Biomolecular and Physical Sciences, Griffith University.

\section{REFERENCES}

1. Hoareau L, DaSilva EJ. Medicinal plants: A re-emerging health aid. Electron J Biotechnol 1999;2:56-70.

2. Lemma A. The potentials and challenges of endod, the Ethiopian soapberry plant for the control of schistosomiasis. Science in Africa: Achievements and Prospects, American Association for the Advancement of Sciences (AAAS), Washington DC, USA, 1991.

3. Sersa G, Krzic M, Sentjurc M, Ivanusa T, Beravs K, Cemazar M, et al. Reduced tumor oxygenation by treatment with vinblastine. Cancer Res 2001;61:4266-71.

4. Reich S, Overberg-Schmidt US, Bührer C, Henze G. Low-dose chemotherapy with vinblastine and methotrexate in childhood desmoid tumors. J Clin Oncol 1999;17:1086-90.

5. Moerman DE. Native American Ethnobotany. Portland, OR, USA: Timber Press; 1998.

6. Roth I, Lindorf H. South American Medicinal Plants - Botany, Remedial Properties and General Use. Berlin, Germany: Springer; 2002.

7. Kalt FR, Cock IE. The medicinal potential of Australian native plants from Toohey Forest, Australia. South Pac J Nat Sci 2010;28:41-7.

8. Cock IE. Antibacterial activity of selected Australian native plant extracts. Internet J Microbiol 2008;4.

9. Cock IE. Assessment of the toxicity of selected Australian native plant extracts using the Artemia franciscana nauplii bioassay. Internet J Toxicol 2009;5.

10. Ryan $M$, editor. Wild plants of greater Brisbane. Brisbane, Australia: Queensland Museum Publications; 2005. p. 187.

11. Cock IE. Medicinal and aromatic plants - Australia. In Ethnopharmacology, Encyclopedia of Life Support Systems (EOLSS), 2011. Developed under the auspices of UNESCO. Oxford, UK: EOLSS Publishers; 2011. Available from: http://www.eolss.net. [Last accessed in 2013 Apr 1].

12. Evans FJ, Taylor SE. Pro-inflammatory, tumor promoting and anti-tumor diterpenes of the plant families Euphorbiaceae and Thymelaeaceae. In: Hertz W, Grisebach H, Kirby GW, editors. Vol. 44. Progress in the Chemistry of Organic Natural Products. Vienna Austria: Springer-Verlag; 1983. p. 1-99.

13. Adolf W, Hecker E. Diterpenoid irritants and cocarcinogens in Euphorbiaceae and Thymelaeaceae: Structural relationships in view of their biogenesis. Israel J Chem 1977;16:75-83.

14. Grace MH, Jin Y, Wilson GR, Coates RM. Structures, biogenetic relationships, and cytotoxicity of primarane-derived diterpenes from Petalostigma pubescens. Phytochemistry 2006;67:1708-15.

15. Coutts RH, Catterall CP. Identifying the plants of Toohey Forest. Nambour, Australia: Ecos Educational Publishers; 1980.

16. Kukkonen L, Cock IE. An examination of the medicinal potential of Scaevola spinescens: Toxicity, antibacterial, and antiviral activities. Pharmacogn Res 2011;3:85-94.

17. Vesoul J, Cock IE. An examination of the medicinal potential of Pittosporum phylliraeoides: Toxicity, antibacterial, and anfungal activities. Pharmacogn Commun 2011;1:8-17.

18. Cock IE, Mohanty S. Evaluation of the antibacterial activity and toxicity of Terminalia ferdinaddiana fruit extracts. Pharmacogn $\mathrm{J}$ 2011;3:72-9.

19. Vesoul J, Cock IE. The potential of Bunya nut extracts as antibacterial functional food agent. Pharmacogn Commun 2012;2:72-79.
20. Mohanty S, Cock IE. Evaluation of the antibacterial activity and toxicity of Myrciaria caulifloria methanolic leaf and fruit extracts. Internet J Microbiol 2009;7.

21. Cock I, Kalt FR. A modified MS2 bacteriophage plaque reduction assay for the rapid screening of antiviral plant extracts. Pharmacogn Res 2010;2:221-8.

22. Cock IE, Ruebhart DR. Comparison of the brine shrimp nauplii bioassay and the ToxScreen-II test for the detection of toxicity associated with Aloe vera (Aloe barbadensis Miller) leaf extract. Pharmacogn Res 2009;1:102-8.

23. Cock IE, Kalt FR. GC-MS analysis of a Xanthorrhoea johnsonii leaf extract displaying apparent anaesthetic effects. J Nat Pharm 2012;3:77-88

24. Meyer BN, Ferrigni NR, Putnam JE, Jacobsen LB, Nichols DE, McLaughlin JL. Brine shrimp: A convenient general bioassay for active plant constituents. Planta Med 1982;45:31-4.

25. Cock IE. Antimicrobial activity of Eucalyptus major and Eucalyptus baileyana methanolic extracts. Internet J Microbiol 2009;6.

26. Setzer MC, Setzer WN, Jackes BR, Gentry GA, Moriarity DM. The medicinal value of tropical rainforest plants from Paluma, North Queensland, Australia, Pharm Biol 2001;39:67-78.

27. Carson CF, Hammer KA, Riley TV. Melaleuca alternifolia (Tea Tree) Oil: A review of antimicrobial and other medicinal properties. Clin Microbiol Rev 2006;19:50-62.

28. Paz EA, Cerdeiras MP, Fernandez J, Ferreira F, Moyna P, Soubes $\mathrm{M}$, et al. Screening of Uruguayan medicinal plants for antimicrobial activity. J Ethnopharmacol 1995;45:67-70.

29. Vlietinck AJ, van Hoof L, Totte J, Lasure A, Vanden Berghe D, Rwangabo PC, et al. Screening of a hundred Rwandese medicinal plants for antimicrobial and antiviral properties. J Ethnopharmacol 1995;46:31-47.

30. Palombo EA, Semple SJ. Antibacterial activity of traditional Australian medicinal plants. J Ethnopharmacol 2001;77:151-7.

31. Semple SJ, Reynolds GD, O'Leary MC, Flower RL. Screening of Australian medicinal plants for antiviral activity. J Ethnopharmacol 1998;60:163-72.

32. Cowan MM. Plant products as antimicrobial agents. Clin Microbiol Rev 1999;12:564-82.

33. Lago JH, Ramos CS, Casanova DC, Morandim AA, Bergamo DC, Cavalheiro AJ, et al. Benzoic acid derivatives from Piper species and their fungitoxic activity against Cladosporium cladosporioides and C. Sphaerospermum. J Nat Prod 2004;67:1783-8.

34. Wilson CO, Gisvold O, Block JH. Wilson and Gisvolds Textbook of Organic Medicinals and Pharmaceuticals. Philadelphia: Lippincott Williams and Wilkins; 2004.

35. Bateman B, Warner JO, Hutchinson E, Dean T, Rowlandson P, Gant C, et al. The effects of double blind, placebo controlled, artificial food colourings and benzoate preservative challenge on hyperactivity in a general population sample of preschool children. Arch Dis Child 2004;89:506-11.

36. Sikkema J, de Bont JA, Poolman B. Mechanisms of membrane toxicity of hydrocarbons. Microbiol Rev 1995;59:201-22.

37. Sirdaarta J, Cock IE. Vitamin E and Trolox ${ }^{\mathrm{TM}}$ reduce toxicity of Aloe barbadensis Miller juice in Artemia franciscana nauplii but individually are toxic at high concentrations. Internet $\mathrm{J}$ Toxicol 2008;5.

38. Morris JA, Kheltry A, Seitz EW. Antimicrobial activity of aroma chemicals and essential oils. J Am Oil Chem Soc 1978;56:595-603.

39. Ghannoum MA, Thomson M, Beadle CD, Bowman WR Antibacterial activity of some $\alpha$-substituted2-methyl-5-nitrofurans. Folia Microbiol 1988;33:198-207.

40. Tomassi C, Van Nhien AN, Marco-Contelles J, Balzarini J, 
Pannecouque C, De Clercq E, et al. Synthesis and anti-HIV1 biological activity of novel 5"-ATSAO compounds. Bioorg Med Chem 2008;16:4733-41.

41. Ghannoum M, Thomson M, Bowman W, Al-Khalil S. Mode of action of the antimicrobial compound 5-bromo-5-nitro-1,3-dioxane (Bronidox). Folia Microbiol (Praha) 1986;31:19-31.

42. Küçük HB, Yusufoğlu $A$, Mataraci E, Döşler $S$. Synthesis and biological activity of new 1,3-dioxolanes as potential antibacterial and antifungal compounds. Molecules 2011;16:6806-15.

43. Kim HY, Patkar C, Warrier R, Kuhn R, Cushman M. Design, synthesis, and evaluation of dioxane-based antiviral agents targeted against the Sindbis virus capsid protein. Bioorg Med Chem Lett 2005;15:3207-11.

Cite this article as: Kalt FR, Cock IE. Gas chromatography-mass spectroscopy analysis of bioactive petalostigma extracts: Toxicity, antibacterial and antiviral activities. Phcog Mag 2014;10:S37-49.

Source of Support: Financial support for this work was provided by School of Biomolecular and Physical Sciences, Griffith University., Conflict of Interest: None declared. 